Article

\title{
Cupric Oxide Nanostructures from Plasma Surface Modification of Copper
}

\author{
Hernando S. Salapare III ${ }^{1,2}, * \mathbb{E}$, Juvy A. Balbarona ${ }^{3}$, Léo Clerc $^{1}$, Pierre Bassoleil ${ }^{1}$, \\ Arnaud Zenerino ${ }^{1}$, Sonia Amigoni ${ }^{1}$ and Frédéric Guittard ${ }^{1,4}$ \\ 1 Université Côte d'Azur, NICE Lab, IMREDD, 06100 Nice, France; lclerc@outlook.fr (L.C.); \\ pa.bassoleil06@gmail.com (P.B.); Arnaud.ZENERINO@univ-cotedazur.fr (A.Z.); \\ Sonia.AMIGONI@univ-cotedazur.fr (S.A.); Frederic.GUITTARD@univ-cotedazur.fr (F.G.) \\ 2 Faculty of Education, University of the Philippines Open University, Los Baños 4030, Laguna, Philippines \\ 3 Department of Mechanical Engineering, College of Engineering University of the Philippines Diliman, \\ Quezon City 1101, Philippines; jabalbarona@gmail.com \\ 4 Department of Bioengineering, University of California Riverside, Materials Science and Engineering \\ Building, 900 University Avenue, Riverside, CA 92521, USA \\ * Correspondence: hssalapare@up.edu.ph or Hernando.SALAPARE@univ-cotedazur.fr
}

Received: 27 February 2019; Accepted: 20 June 2019; Published: 25 June 2019

\begin{abstract}
Taking inspiration from the hydrophilic and superhydrophilic properties observed from the nanostructures present on the leaves of plants such as Alocasia odora, Calathea zebrina, and Ruelia devosiana, we were able to synthesize cupric oxide $(\mathrm{CuO})$ nanostructures from the plasma surface modification of copper $(\mathrm{Cu})$ that exhibits hydrophilic and superhydrophilic properties. The $\mathrm{Cu}$ sheets were exposed to oxygen plasma produced from the P300 plasma device (Alliance Concept, Cran-Gevrier, France) at varying power, irradiation times, gas flow rates, and pulsing duty cycles. The untreated and plasma-treated $\mathrm{Cu}$ sheets were characterized by contact angle measurements, scanning electron microscopy (SEM), and energy dispersive spectroscopy (EDS) to determine the changes in the surface of $\mathrm{Cu}$ before and after plasma treatment. Results showed that plasma-treated $\mathrm{Cu}$ sheets exhibited enhanced wetting properties compared to untreated $\mathrm{Cu}$. We attributed the decrease in the measured water contact angles after plasma treatment to increased surface roughness, formation of $\mathrm{CuO}$ nanostructures, and transformation of $\mathrm{Cu}$ to either $\mathrm{CuO}_{2}$ or $\mathrm{Cu}_{2} \mathrm{O}_{3}$. The presence of the $\mathrm{CuO}$ nanostructures on the surface of $\mathrm{Cu}$ is very useful in terms of its possible applications, such as: (1) in antimicrobial and anti-fouling tubing; (2) in the improvement of heat dissipation devices, such as microfluidic cooling systems and heat pipes; and (3) as an additional protection to $\mathrm{Cu}$ from further corrosion. This study also shows the possible mechanisms on how $\mathrm{CuO}, \mathrm{CuO}_{2}$, and $\mathrm{Cu}_{2} \mathrm{O}_{3}$ were formed from $\mathrm{Cu}$ based on the varying the plasma parameters.
\end{abstract}

Keywords: cupric oxide; copper; bio-inspired material; nanostructures; oxygen plasma; surface modification; hydrophilic

\section{Introduction}

In past decades, the mimicking of nature has been very successful in solving global environmental, material, and sustainability problems due to the superior physical and chemical properties exhibited by different animals, plants, and microorganisms [1-8]. As an example, leaves of plants such as Alocasia odora, Calathea zebrina, and Ruelia devosiana show nanostructures that exhibit hydrophilic and superhydrophilic properties [6,7]. Aside from the surface morphology, the surface and bulk chemistry of the leaves of these plants also contribute to the exhibited wetting properties [6]. Mimicking these nanostructures to attain the same wetting properties can be achieved using different techniques, 
such as surface modification of polymeric or metallic materials by flame, chemical, laser, or plasma processes [1-10].

In recent years, plasma technologies have been widely used, due to its ability to modify the surface chemistry and surface morphology of a material by taking advantage of the presence of complex mixtures of ions, electrons, atoms, and radical species in the plasma [11,12].

Copper $(\mathrm{Cu})$ metal and its oxides, such as cupric oxide $(\mathrm{CuO})$ and cuprous oxide $\left(\mathrm{Cu}_{2} \mathrm{O}\right)$ has been widely studied, due to its chemical and physical properties that makes it advantageous in such applications as sensing, energy, electronics, tubing, and aeronautical industries [13-21]. Hydrophilic $\mathrm{CuO}$ nanostructures on $\mathrm{Cu}$ are useful in terms of its possible applications, such as: (1) in antimicrobial and anti-fouling tubing; (2) in the improvement of heat dissipation devices, such as microfluidic cooling systems and heat pipes; and (3) as an additional protection to the $\mathrm{Cu}$ from further corrosion [13-15,22]. Much research has been done on the formation of $\mathrm{CuO}$ and $\mathrm{Cu}_{2} \mathrm{O}$ by thermal oxidation [23-27], but only a few presents the use of plasma technology. Some of these studies are the functionalization of $\mathrm{Cu}$ surfaces by plasma treatments in improving the adhesion of epoxy resins [16] and the effects of different gases in the plasma treatment of the $\mathrm{Cu}$ surface of capacitors [17]. Although the applications of $\mathrm{CuO}$ formations from the plasma treatment of $\mathrm{Cu}$ have already been reported in the literature $[16,17,28,29]$, there is still a need to explain the mechanisms on how varying the plasma parameters affects the formation of $\mathrm{CuO}$ and $\mathrm{Cu}_{2} \mathrm{O}$.

In this study, we used oxygen plasma with varying plasma parameters (power, irradiation time, gas flow rate, and pulsed plasma duty cycle) to form $\mathrm{CuO}$ and $\mathrm{Cu}_{2} \mathrm{O}$ directly from $\mathrm{Cu}$. The wetting properties of the plasma-treated $\mathrm{Cu}$ samples were explained by the changes in the surface roughness, surface morphology, and the formations of $\mathrm{CuO}$ and $\mathrm{Cu}_{2} \mathrm{O}$. The mechanism on the formations of $\mathrm{CuO}$, $\mathrm{Cu}_{2} \mathrm{O}$, and the intermediate-phase $\mathrm{Cu}_{2} \mathrm{O}_{3}$ was explained based on the varying plasma parameters.

\section{Materials and Methods}

\subsection{Materials and Plasma Surface Modification}

Cu sheets (CAS 7440-50-8: 99.35\% purity, $63.55 \mathrm{MW}, 0.034 \mathrm{~mm}$ thickness) were obtained from GoodFellow, France. The samples were cut into $1 \mathrm{~cm} \times 3 \mathrm{~cm}$ sizes and used without further cleaning.

The $\mathrm{Cu}$ samples were irradiated with oxygen plasma produced from a P300 plasma device (Alliance Concept, Cran-Gevrier, France). Figure 1 shows the schematic diagram of the P300 plasma device with a vacuum chamber of $300 \mathrm{~mm} \times 300 \mathrm{~mm} \times 300 \mathrm{~mm}$ dimension, an electrode with a diameter of $10 \mathrm{~cm}$, and operation at an excitation frequency of $13.56 \mathrm{MHz}$. The chamber was first evacuated using a $20 \mathrm{~m}^{3} / \mathrm{h}$ rotary pump, and the base pressure was achieved at $8.0 \times 10^{-2}$ mbar before plasma ignition. Oxygen gas was then injected inside the vacuum chamber at varying flow rates of $10 \mathrm{sccm}$, $15 \mathrm{sccm}$, and $20 \mathrm{sccm}$ at operating pressures of $1.55 \times 10^{-1} \mathrm{mbar}, 1.97 \times 10^{-1} \mathrm{mbar}$, and $2.24 \times 10^{-1} \mathrm{mbar}$, respectively. The pulsing duty cycles were varied from $0 \%, 50 \%$, and $80 \%$. Power and irradiation times were also varied from $100 \mathrm{~W}, 300 \mathrm{~W}$, and $600 \mathrm{~W}$, and $60 \mathrm{~s}, 180 \mathrm{~s}$, and $300 \mathrm{~s}$, respectively. Table 1 shows the summary of the plasma surface modification parameters. 


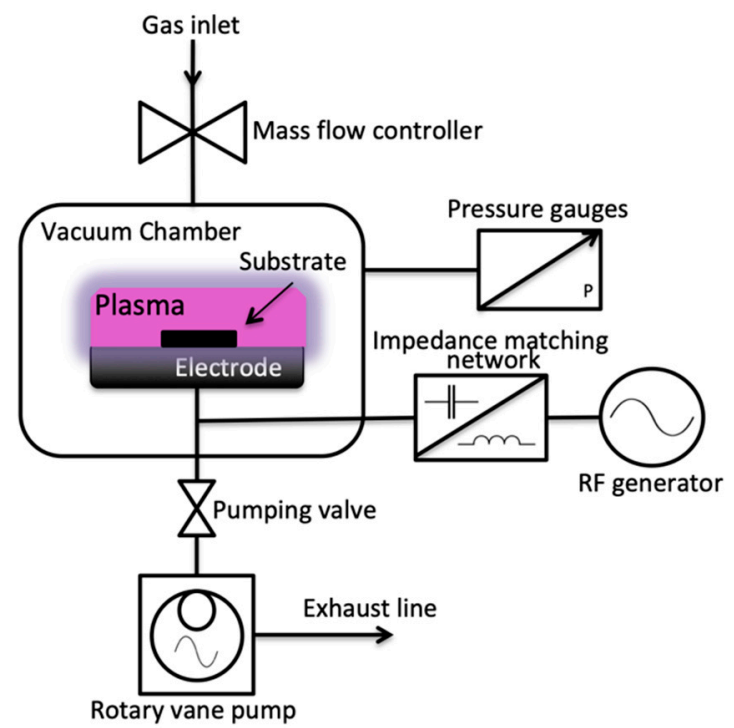

Figure 1. Schematic diagram of the P300 plasma device.

Table 1. Summary of the plasma surface modification parameters and the corresponding water contact angle measurements.

\begin{tabular}{|c|c|c|c|c|c|c|c|c|}
\hline Sample & & $\begin{array}{l}\text { Power } \\
\text { (W) }\end{array}$ & $\begin{array}{l}\text { Irradiation } \\
\text { Time (s) }\end{array}$ & $\begin{array}{l}\mathrm{O}_{2} \text { Gas Flow } \\
\text { Rate (sccm) }\end{array}$ & $\begin{array}{c}\text { Duty } \\
\text { Cycle (\%) }\end{array}$ & $\begin{array}{l}\text { Water Contact } \\
\text { Angle }\left({ }^{\circ}\right)(0 \text { Days } \\
\text { after Plasma } \\
\text { Treatment) }\end{array}$ & $\begin{array}{l}\text { Water Contact } \\
\text { Angle }\left({ }^{\circ}\right)(30 \text { Days } \\
\text { after Plasma } \\
\text { Treatment) }\end{array}$ & $\begin{array}{l}\text { Water Contact } \\
\text { Angle }\left(^{\circ}\right) \text { (60 Days } \\
\text { after Plasma } \\
\text { Treatment) }\end{array}$ \\
\hline \multicolumn{2}{|l|}{$\mathrm{Cu}-0^{\mathrm{a}}$} & \multicolumn{4}{|c|}{ Untreated } & \multicolumn{3}{|c|}{$116 \pm 2$} \\
\hline \multirow{3}{*}{ Varying Power } & $\mathrm{Cu}-1$ & 100 & 300 & 20 & 80 & $22 \pm 2$ & $23 \pm 3$ & $24 \pm 3$ \\
\hline & $\mathrm{Cu}-2^{\mathrm{a}}$ & 200 & 300 & 20 & 80 & $<10$ & $<10$ & $<10$ \\
\hline & $\mathrm{Cu}-3$ & 300 & 300 & 20 & 80 & $<10$ & $<10$ & $<10$ \\
\hline \multirow{2}{*}{$\begin{array}{c}\text { Varying } \\
\text { Irradiation Time }\end{array}$} & $\mathrm{Cu}-4$ & 300 & 60 & 20 & 80 & $<10$ & $<10$ & $<10$ \\
\hline & $\mathrm{Cu}-5$ & 300 & 180 & 20 & 80 & $<10$ & $<10$ & $<10$ \\
\hline \multirow{2}{*}{$\begin{array}{l}\text { Varying } \mathrm{O}_{2} \text { Gas } \\
\text { Flow Rate }\end{array}$} & $\mathrm{Cu}-6$ & 300 & 300 & 10 & 80 & $15 \pm 1$ & $16 \pm 2$ & $16 \pm 1$ \\
\hline & $\mathrm{Cu}-7$ & 300 & 300 & 15 & 80 & $<10$ & $<10$ & $<10$ \\
\hline \multirow{2}{*}{$\begin{array}{l}\text { Varying } \\
\text { Duty Cycle }\end{array}$} & $\mathrm{Cu}-8$ & 300 & 300 & 20 & 0 & $34 \pm 1$ & $35 \pm 3$ & $36 \pm 2$ \\
\hline & $\mathrm{Cu}-9$ & 300 & 300 & 20 & 50 & $24 \pm 1$ & $24 \pm 1$ & $25 \pm 2$ \\
\hline
\end{tabular}

${ }^{a} \mathrm{Cu}-\mathrm{O}$ and $\mathrm{Cu}-2$ were also used to compare the effects of the plasma treatment of $\mathrm{Cu}$ with varying irradiation times, gas flow rates, and duty cycles.

\subsection{Characterizations}

\subsubsection{Water Contact Angle Measurements}

Changes in the wettability of the untreated and plasma-treated $\mathrm{Cu}$ samples were determined using a DSA-30 goniometer (Krüss GmbH, Hamburg, Germany) equipped with drop shape analysis (DSA4) software (Krüss $\mathrm{GmbH}$ ). The sessile drop method was utilized to determine the apparent contact angles. Two $\mu \mathrm{L}$ of Milli-Q deionized water was dropped vertically onto the samples using a motorized syringe mechanism. For each sample, water contact angles were measured at five different sites, and the standard deviation of the contact angle measurements at different sites were all statistically the same. All contact angle measurements were recorded at the same humidity and temperature conditions. Water contact angle measurements were performed 0 days, 30 days, and 60 days after plasma treatment to determine the aging effects on the $\mathrm{Cu}$ samples.

\subsubsection{Scanning Electron Microscopy (SEM)}

The surface morphology of the untreated and plasma-treated $\mathrm{Cu}$ samples were obtained using a Phenom ProX SEM (Phenom World B.V., France Scientifique, Saint Genis Laval, France) at $15 \mathrm{kV}$ accelerating voltage and at a secondary electron detector (SED) imaging mode. The SEM micrographs were reported at 10,000 $\times$ magnification. 


\subsubsection{Energy Dispersive Spectroscopy (EDS)}

The elemental compositions of the untreated and plasma-treated $\mathrm{Cu}$ samples were determined from the $15 \mathrm{kV}$ analysis mode of the SEM described in the preceding section. The detector used in the EDS is a Silicon Drift Detector (SDD) with an ultra-thin silicon nitride $\left(\mathrm{Si}_{3} 3 \mathrm{~N}_{4} 4\right)$ X-ray window that allows the accurate detection of elements from $\mathrm{B}$ to $\mathrm{Am}$, with an energy resolution of $\mathrm{Mn} \mathrm{K} \alpha \leq 137 \mathrm{eV}$, and with a resolution limit of $\leq 14 \mathrm{~nm}$. Nanostructures on the plasma-treated $\mathrm{Cu}$ samples were examined at $10 \mathrm{kV}$ analysis modes in order to have more accurate counts at dimensions of less than $1 \mu \mathrm{m}$. Phenom ProSuite v2.8.2 Element Identification Software (Phenom World B.V., France Scientifique, Saint Genis Laval, France) was used to calculate the atomic concentration of the elemental components using the SED mode. All the EDS calculations are within $\pm 15 \%$ error from the theoretical values.

\section{Results and Discussion}

\subsection{Water Contact Angle Measurements}

The water contact angle measurements are shown in Table 1 with the corresponding plasma surface modification parameters. It can be observed that all plasma-treated $\mathrm{Cu}$ samples exhibited enhanced wetting properties. The sample became hydrophilic at lower power and exhibited superhydrophilic properties at higher power. The decrease in water contact angle as the power increases is attributed to the increase in interactions of the different plasma species with the samples, which either leads to an increase in the surface roughness, or changes in the chemistry of the material $[7,10]$.

When the irradiation times were varied while maintaining the power at $300 \mathrm{~W}$, all the plasma-treated $\mathrm{Cu}$ samples exhibited superhydrophilic properties. This means that as long as the power is high, lesser time is needed to achieve superhydrophilic properties.

Increasing the gas flow rate also increases the wetting properties of the samples. A lower gas flow rate produced hydrophilic surfaces, while a higher gas flow rate exhibited superhydrophilic properties. Increasing the gas flow rate increases the pressure inside the chamber, meaning that there are more plasma species that are produced that can interact with the samples.

Changing the pulsing duty cycle of the plasma strongly modifies the plasma that interacts with the sample. A lower duty cycle means less dissociated plasmas, which means that the chemical effects of the plasma are greater than the physical consequences which occur to the sample. This was exhibited by obtaining hydrophilic surfaces at a lower duty cycle, while superhydrophilic properties were obtained at a higher duty cycle. The physical effects of the plasma on the surface, like etching, increasing surface roughness, or producing nanostructures are more enhanced when the duty cycle is higher. A lower duty cycle of pulsed plasmas reduces the physical damage that the plasma can bring to the sample. Normally, a lower duty cycle is favorable only when the etching of a material is desired [30-32].

Water contact angles measurements were also performed 30 days and 60 days after plasma treatment, as shown in Table 1, where the rate of hydrophobic recovery is visibly very slow and the changes of contact angles over time are insignificant. This means that the copper oxides formed were stable and favorable for future industrial applications.

\subsection{Scanning Electron Microscopy (SEM)}

Figure 2 shows the SEM micrographs of the $\mathrm{Cu}$ samples subjected to oxygen plasma with varying power. A smoother surface morphology can be seen for the untreated $\mathrm{Cu}$ samples, while plasma-treated $\mathrm{Cu}$ samples exhibited increased surface roughness, especially for higher power plasma treatments where $\mathrm{CuO}$ nanostructures (with an average diameter of $106 \mathrm{~nm}$ ) were formed on the surface. In Figure 2d, it can be seen that some of the surface layer is bursting at $600 \mathrm{~W}$ plasma treatment, which may be due to oxygen gases trapped in the surface because of the thermal oxidation of $\mathrm{Cu}$. The increase in the surface roughness and the presence of the nanostructures in the surface of the material is responsible for the superhydrophilic properties at higher power plasma treatments. Plasma 
treatment at $600 \mathrm{~W}$ resulted in more damage to the surface of the $\mathrm{Cu}$ sample, where the top layer is visibly starting to burst.

Figure 3 shows the SEM micrographs of the $\mathrm{Cu}$ samples subjected to oxygen plasma with varying irradiation times. The formation of the $\mathrm{CuO}$ nanostructures can be traced as the irradiation time increases. Longer exposure of the $\mathrm{Cu}$ sample to the plasma species is necessary to attain the change in surface chemistry which results in the $\mathrm{CuO}$ nanostructures. This is due to the high activation energy needed to produce $\mathrm{CuO}$ from $\mathrm{Cu}$, or from its $\mathrm{CuO}_{2}$ precursor, as shown in Table 2 .

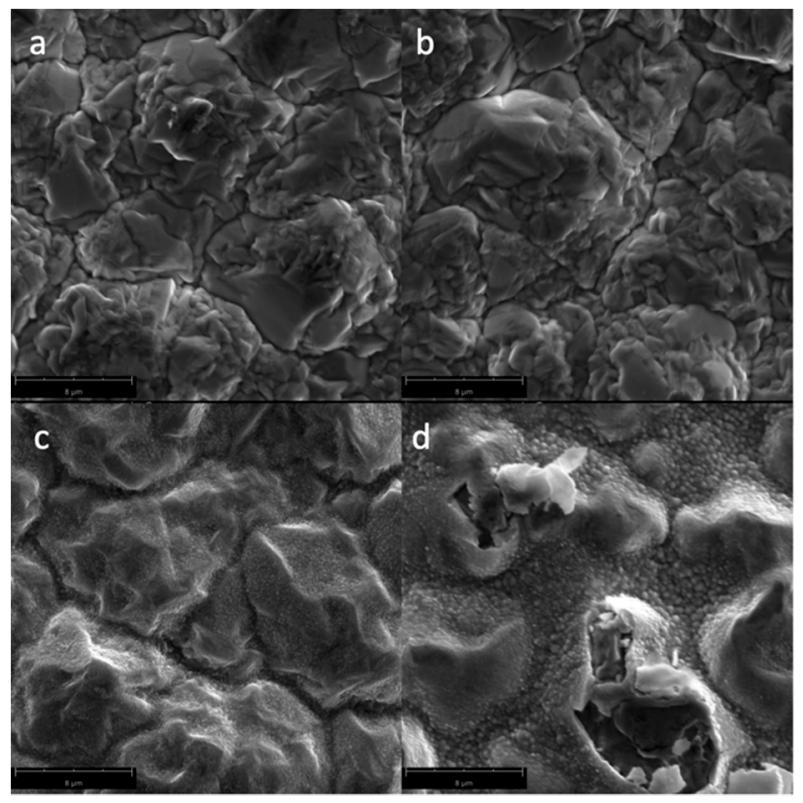

Figure 2. Scanning Electron Microscopy (SEM) micrographs of the surfaces of the Cu samples (magnified at $10,000 \times$ ) subjected to oxygen plasma with varying powers: (a) untreated; (b) $100 \mathrm{~W}$; (c) $300 \mathrm{~W}$; and (d) $600 \mathrm{~W}$.

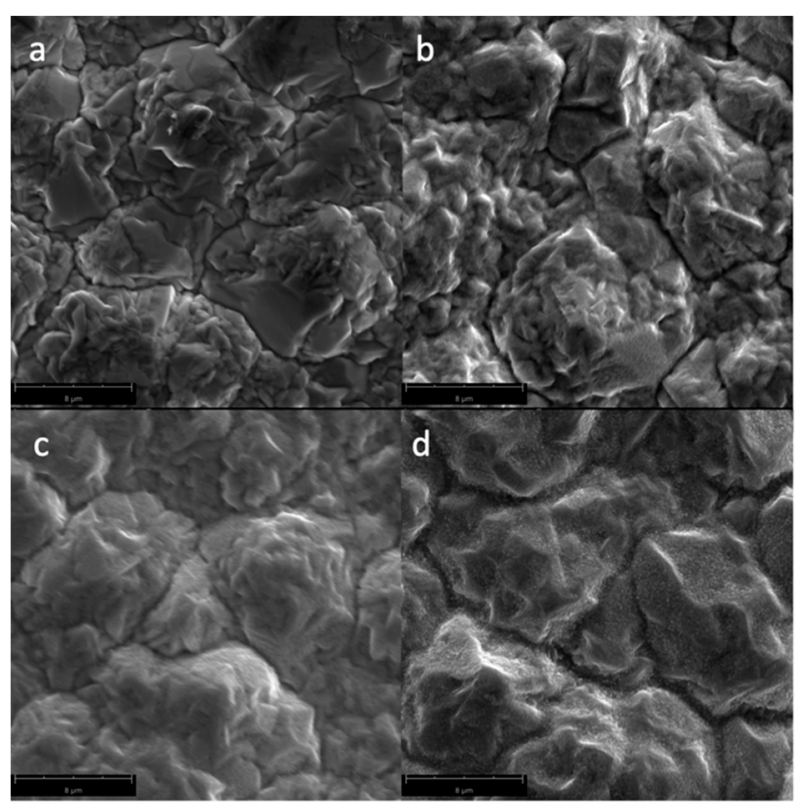

Figure 3. SEM micrographs of the surfaces of the Cu samples (magnified at $10,000 \times$ ) subjected to oxygen plasma with varying irradiation times: (a) untreated; (b) $60 \mathrm{~s}$; (c) $180 \mathrm{~s}$; and (d) $300 \mathrm{~s}$. 
Table 2. Model reaction set with the corresponding activation energy of the products.

\begin{tabular}{cccc}
\hline Reaction No. & Reaction & Activation Energy (kJ/mol) & Reference \\
\hline 1 & $4 \mathrm{Cu}+\mathrm{O}_{2} \leftrightarrow 2 \mathrm{Cu}_{2} \mathrm{O}$ & $111\left(\mathrm{~T}=600-800^{\circ} \mathrm{C}\right)$ & {$[20]$} \\
2 & $2 \mathrm{Cu}+\mathrm{O}_{2} \leftrightarrow 2 \mathrm{CuO}$ & 191 & {$[21]$} \\
3 & $2 \mathrm{Cu}_{2} \mathrm{O}+\mathrm{O}_{2} \leftrightarrow 4 \mathrm{CuO}$ & $168\left(\mathrm{~T}<700^{\circ} \mathrm{C}\right)$ & {$[19]$} \\
4 & $\mathrm{Cu}_{2} \mathrm{O}+\mathrm{O}_{2} \leftrightarrow \mathrm{Cu}_{2} \mathrm{O}_{3}$ & $143\left(\mathrm{~T}=700^{\circ} \mathrm{C}\right)$ & Present work \\
\hline
\end{tabular}

Figure 4 shows the SEM micrographs of the $\mathrm{Cu}$ samples subjected to oxygen plasma with varying gas flow rates. Since the power and irradiation times were kept constant at $300 \mathrm{~W}$ and $300 \mathrm{~s}$, respectively, $\mathrm{CuO}$ nanostructures could form, even at the lower gas flow rate of $10 \mathrm{sccm}$.

Figure 5 shows the SEM micrographs of the $\mathrm{Cu}$ samples subjected to pulsed oxygen plasma with varying duty cycles. The $\mathrm{CuO}$ nanostructures are more prominent at the $50 \%$ and $80 \%$ duty cycle than the $0 \%$ pulsing. These observations are in accordance with the water contact angle measurements presented in Section 3.1.

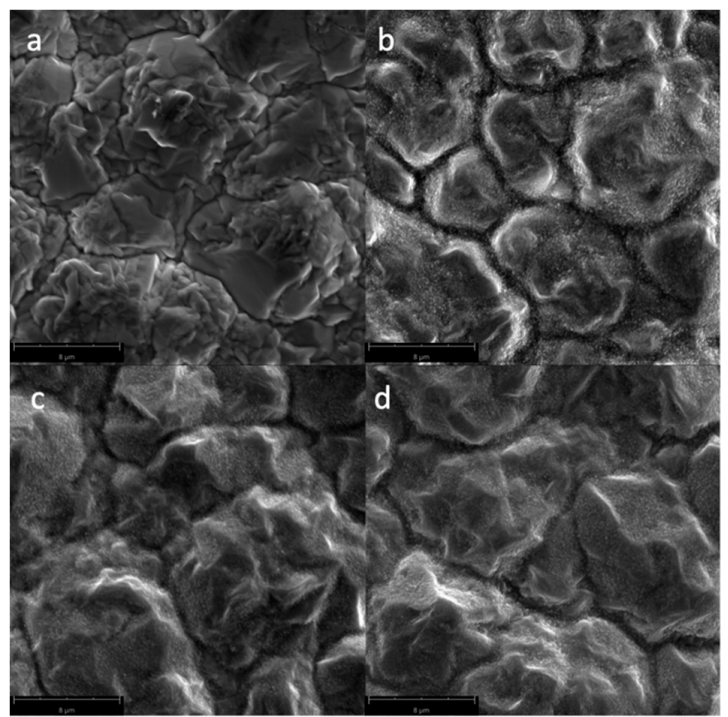

Figure 4. SEM micrographs of the surfaces of the Cu samples (magnified at $10,000 \times$ ) subjected to oxygen plasma with varying $\mathrm{O}_{2}$ gas flow rates: (a) untreated; (b) $10 \mathrm{sccm}$; (c) $15 \mathrm{sccm}$; and (d) $20 \mathrm{sccm}$.

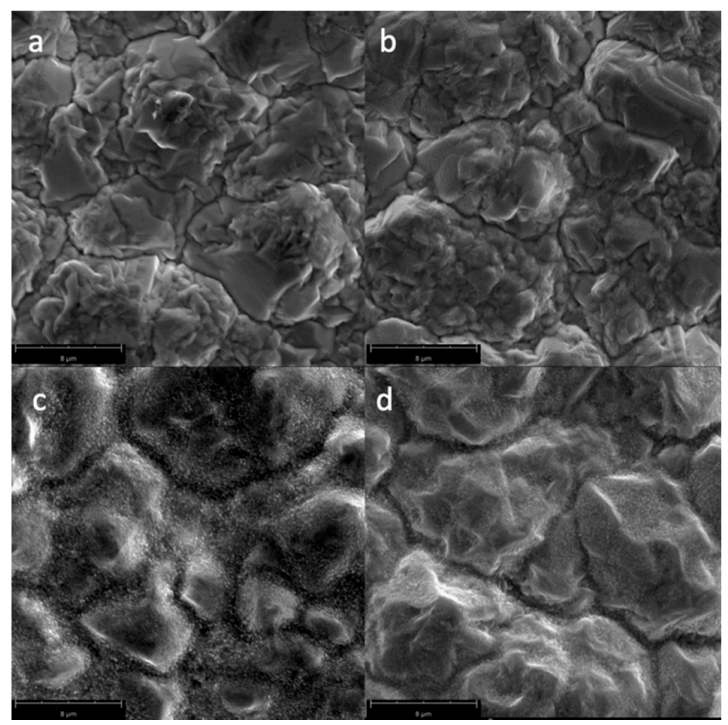

Figure 5. SEM micrographs of the surfaces of the Cu samples (magnified at $10,000 \times$ ) subjected to varying pulsed oxygen plasmas with duty cycles: (a) untreated; (b) no pulsing; (c) 50\%; and (d) $80 \%$. 


\subsection{Energy Dispersive Spectroscopy (EDS)}

$\mathrm{CuO}, \mathrm{Cu}_{2} \mathrm{O}$, and $\mathrm{Cu}_{2} \mathrm{O}_{3}$ were formed in the surface of plasma-treated samples after analyzing the atomic concentrations of $\mathrm{Cu}$ and $\mathrm{O}$ from the EDS spectra. Figure 6 shows a representative SEM micrograph of oxygen plasma-treated $\mathrm{Cu}$, showing $\mathrm{CuO}$ nanostructures (indicated by the blue arrow) and $\mathrm{Cu}_{2} \mathrm{O}$ (indicated by the red arrow). For reference, the theoretical atomic concentration of $\mathrm{CuO}$ is $79.89 \% \mathrm{Cu}$ and $20.11 \% \mathrm{O}$, whereas for $\mathrm{Cu}_{2} \mathrm{O}$, it is $88.82 \% \mathrm{Cu}$ and $11.18 \% \mathrm{O}$.

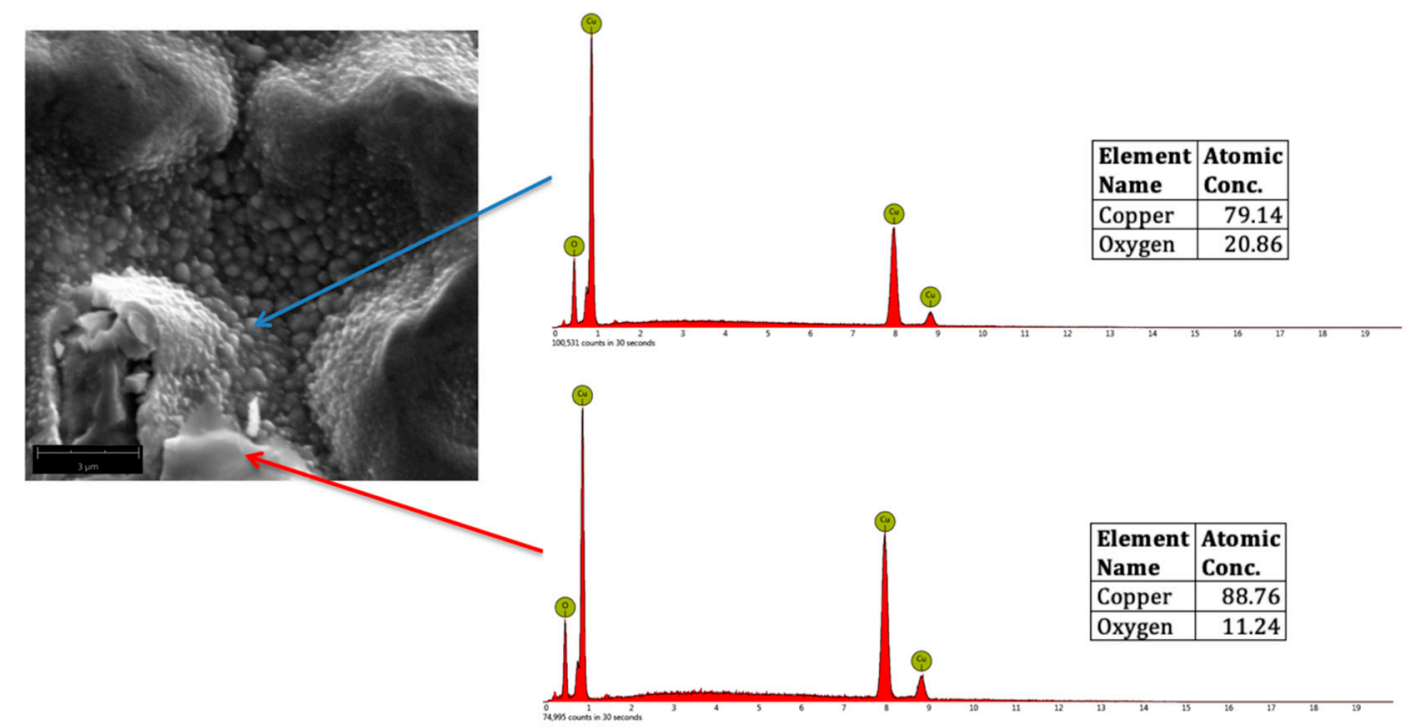

Figure 6. Representative SEM micrograph (magnified at 20,000x) of oxygen plasma-treated $\mathrm{Cu}$, showing $\mathrm{CuO}$ (blue arrow) and $\mathrm{Cu}_{2} \mathrm{O}$ (red arrow) with the corresponding Energy Dispersive Spectroscopy (EDS) spectra.

Figure 7 shows a representative SEM micrograph of oxygen plasma-treated $\mathrm{Cu}$, showing $\mathrm{CuO}$ nanostructures (indicated by the blue arrow) and $\mathrm{Cu}_{2} \mathrm{O}_{3}$ (indicated by the red arrow). For reference, $\mathrm{Cu}_{2} \mathrm{O}_{3}$ is $72.59 \% \mathrm{Cu}$ and $27.41 \% \mathrm{O}$.

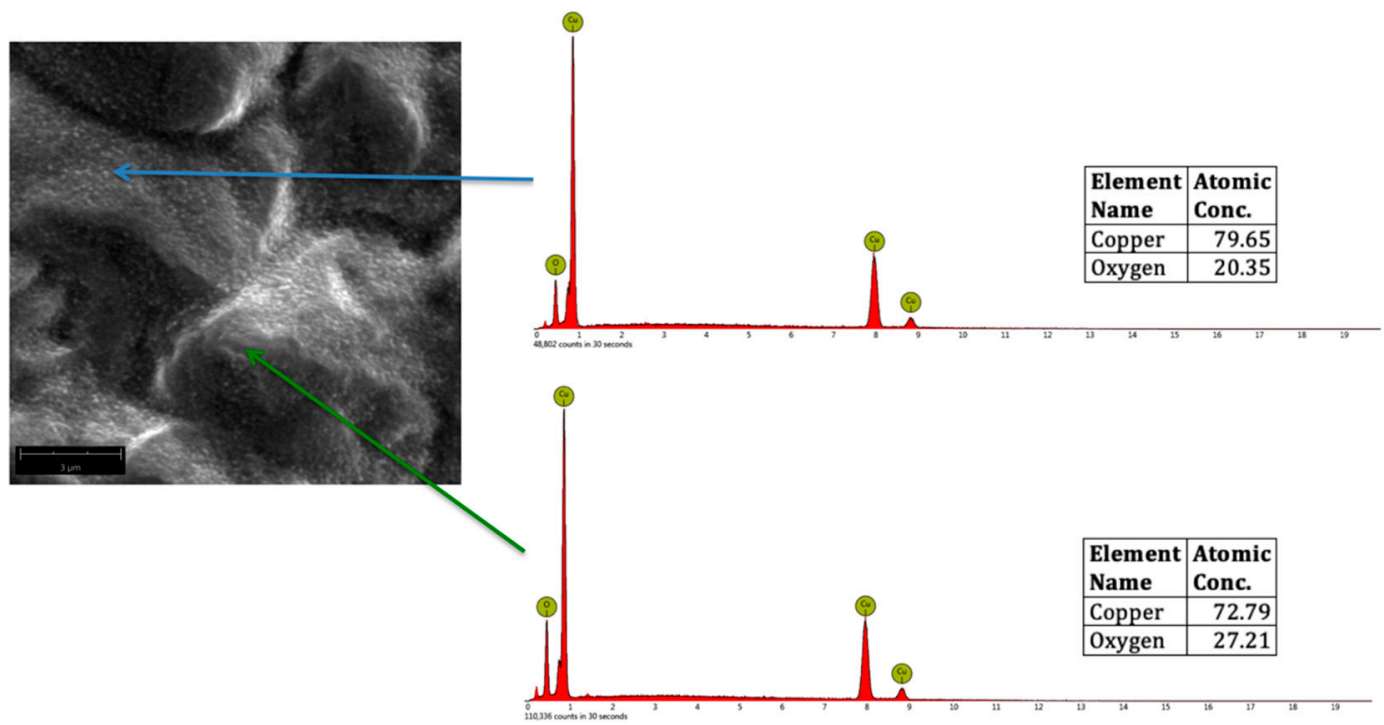

Figure 7. Representative SEM micrograph (magnified at 20,000×) of oxygen plasma-treated $\mathrm{Cu}$, showing $\mathrm{CuO}$ (blue arrow) and $\mathrm{Cu}_{2} \mathrm{O}_{3}$ (green arrow) with the corresponding EDS spectra.

Figure 8 summarizes the oxidations of $\mathrm{Cu}$, namely, $\mathrm{CuO}, \mathrm{Cu}_{2} \mathrm{O}$, and $\mathrm{Cu}_{2} \mathrm{O}_{3}$ from the plasma surface modification of $\mathrm{Cu}$, with increasing: (a) power; (b) irradiation time; (c) $\mathrm{O}_{2}$ gas flow rate; 
and (d) duty cycle. The images of the actual samples can also be seen with the corresponding chemical elements and compounds, as confirmed from the EDS spectra. Those with two oxides written on the sample means that both of them existed on the surface of the $\mathrm{Cu}$ sample. For example, at the $600 \mathrm{~W}$ plasma treatments, both $\mathrm{CuO} / \mathrm{Cu}_{2} \mathrm{O}$ is written, which means that $\mathrm{CuO}$ nanostructures were found on the surface of the $\mathrm{Cu}_{2} \mathrm{O}$.

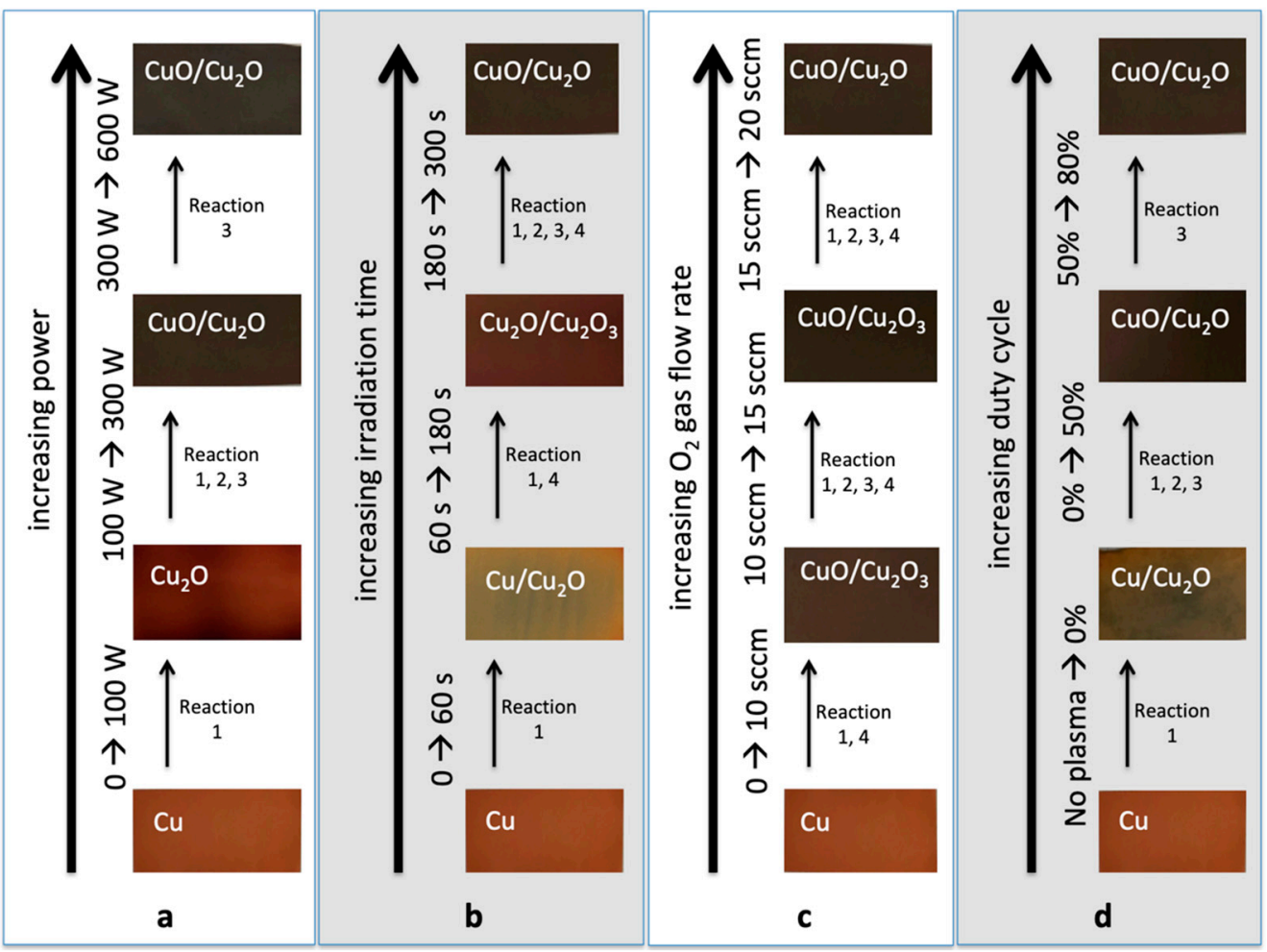

Figure 8. Mechanism of $\mathrm{CuO}, \mathrm{Cu}_{2} \mathrm{O}$, and $\mathrm{Cu}_{2} \mathrm{O}_{3}$ formations from the plasma surface modification of $\mathrm{Cu}$, with increasing: (a) power; (b) irradiation time; (c) $\mathrm{O}_{2}$ gas flow rate; and (d) duty cycle. The images of the actual samples can also be seen with the corresponding chemical elements and compounds.

The color of the actual plasma-treated $\mathrm{Cu}$ samples also provided evidence on whether $\mathrm{CuO}$ nanostructures (usually black in color) or $\mathrm{Cu}_{2} \mathrm{O}$ (usually red in color) had formed on the surface of the material.

Figure 8 also outlines the possible mechanisms on how $\mathrm{CuO}, \mathrm{Cu}_{2} \mathrm{O}$, and $\mathrm{Cu}_{2} \mathrm{O}_{3}$ formed, based on the varying plasma parameters. The model reaction set outlined in Table 2 is used to explain the possible major reactions involved in the $\mathrm{O}_{2}$ plasma treatment of $\mathrm{Cu}$.

In Figure 8a, reaction 1 is the most probable reaction that might occur when the $\mathrm{Cu}$ is exposed to $100 \mathrm{~W}$ plasma. This is seen from the formation of the $\mathrm{Cu}_{2} \mathrm{O}$ which has a lower activation energy compared to the other form of oxides, as explained in Section 3.1. Higher plasma interactions with the sample at higher power enabled reactions 2 and 3 to occur, in order to obtain $\mathrm{CuO}$ nanostructures from the $\mathrm{Cu}_{2} \mathrm{O}$ precursor.

Figure $8 \mathrm{~b}$ shows the possible reactions that might occur when the irradiation time is increased. At $60 \mathrm{~s}$, the sample showed the formation of $\mathrm{Cu}_{2} \mathrm{O}$, which has lower activation energy, from $\mathrm{Cu}$. It also shows that before obtaining $\mathrm{CuO}$ nanostructures, an intermediate-phase $\mathrm{Cu}_{2} \mathrm{O}_{3}$ was formed, which has an activation energy that is slightly lower than when obtaining $\mathrm{CuO}$ from reactions 2 and 3.

Figure $8 \mathrm{c}$ shows the possible reactions that might occur when the $\mathrm{O}_{2}$ gas flow rate is increased. Since the power and irradiation time were maintained at $300 \mathrm{~W}$ and $300 \mathrm{~s}$, respectively, it shows us that $\mathrm{CuO}$ can be formed even at a low gas flow rate of $10 \mathrm{sccm}$, since the activation energy to create $\mathrm{CuO}$ from reaction 1 might have been achieved due to high power and irradiation time. The formation of $\mathrm{Cu}_{2} \mathrm{O}_{3}$ from $10 \mathrm{sccm}$ and $15 \mathrm{sccm}$ was due to the relatively lower pressure compared to $20 \mathrm{sccm}$. 
Figure $8 \mathrm{~d}$ shows the possible reactions that might occur when the duty cycle of the pulsed plasma is increased. As expected, there were still no $\mathrm{CuO}$ formations on the $0 \%$ duty cycle, which is in accordance with the discussion in Sections 3.1 and 3.2.

Increasing the power, irradiation time, gas flow rate, and duty cycle increases the plasma temperature and pressure, which also increases the plasma energy that gets in contact with the $\mathrm{Cu}$ sample. These results are in accordance with the study of Choudhary et al. [18] in the oxidation mechanism of $\mathrm{Cu}$ from the assisted thermal evaporation technique, where the formation of $\mathrm{Cu}_{2} \mathrm{O}$ was achieved between the temperatures of $150{ }^{\circ} \mathrm{C}$ and $320^{\circ} \mathrm{C}$, while $\mathrm{CuO}$ can be converted from $\mathrm{Cu}_{2} \mathrm{O}$ at temperatures above $330^{\circ} \mathrm{C}$ and longer durations.

For all the plasma-treated Cu samples, EDS and SEM results show that the effects of the oxygen plasma can be observed from depths of $2.5 \mu \mathrm{m}$ to $3.0 \mu \mathrm{m}$ from the surface of the $\mathrm{Cu}$ samples. At these thicknesses, complete or partial oxidation of $\mathrm{Cu}$ occurred, as evidenced by the formation of the different copper oxides shown in Figure 8. The thicknesses of the copper oxides formed in the surface of the $\mathrm{Cu}$ samples do not affect the overall wetting properties observed in the material. This also means that the modification of the $\mathrm{Cu}$ sample to attain hydrophilic and superhydrophilic properties is not only due to the nanostructures on the surface, but also the changes in the chemistry of the material. Comparing this study with the research conducted by Li and Hess [33] where $\mathrm{Cu}$ films were oxidized using oxygen plasma discharge, the plasma effects on the $\mathrm{Cu}$ samples-primarily the thermal oxidation-also increased as the plasma power increased.

\section{Conclusions}

$\mathrm{CuO}$ nanostructures formed from the plasma surface modification of $\mathrm{Cu}$ exhibited hydrophilic and superhydrophilic properties from the measured water contact angles of less than $90^{\circ}$ or $<10^{\circ}$, where the liquid drop was shown to spread on the samples' surfaces within $1 \mathrm{~s}$ of contact. These enhanced wetting properties are comparable with the hydrophilic and superhydrophilic properties observed from the nanostructures present on the leaves of plants such as Alocasia odora, Calathea zebrina, and Ruelia devosiana. The decrease in the water contact angles with increasing power, irradiation time, gas flow rate, and duty cycle can be attributed to the increased surface roughness and the formation of $\mathrm{CuO}$ nanostructures, as well as the transformation of $\mathrm{Cu}$ to either $\mathrm{CuO}_{2}$ or $\mathrm{Cu}_{2} \mathrm{O}_{3}$, as confirmed by the EDS spectra and SEM images. The presence of the $\mathrm{CuO}$ nanostructures on the surface of $\mathrm{Cu}$ is very useful in terms of its possible applications, such as: (1) in antimicrobial and anti-fouling tubing; (2) in the improvement of heat dissipation devices, such as microfluidic cooling systems and heat pipes; and (3) as an additional protection to the $\mathrm{Cu}$ from further corrosion. Increasing the plasma power enhances the formation of $\mathrm{CuO}$ nanostructures, since higher plasma power can produce more energetic plasma species, which can easily attain the activation energy needed to produce $\mathrm{CuO}$. The variation in the irradiation time and gas flow rate showed the process from forming $\mathrm{CuO}$ from $\mathrm{Cu}, \mathrm{Cu}_{2} \mathrm{O}$, and the intermediate-phase $\mathrm{Cu}_{2} \mathrm{O}_{3}$. The higher activation energy needed to produce $\mathrm{CuO}$ nanostructures can be attained at higher duty cycles, due to the increased dissociation in the plasma.

Author Contributions: Conceptualization, H.S.S., J.A.B., L.C., P.B.; methodology, H.S.S., J.A.B., L.C., P.B. A.Z.; formal analysis, H.S.S., J.A.B., A.Z., S.A., F.G.; investigation, H.S.S., J.A.B., L.C., P.B.; writing-original draft preparation, H.S.S.; writing-review and editing, H.S.S., J.A.B.; visualization, H.S.S.; supervision, S.A., F.G.; project administration, H.S.S.; funding acquisition, J.A.B., F.G.

Funding: This research was partly funded by the Engineering Research and Development for Technology (ERDT) scholarship, Science Education Institute (SEI) - Department of Science and Technology (DOST), Philippines for the mobility of Juvy A. Balbarona. The SEM and EDS characterizations were carried out at the "Smart City Innovation Center" that was financed under the "Plan Etat Région 2015-2020|" of Provence-Alpes-Côte d'Azur, France.

Acknowledgments: The authors would like to acknowledge the assistance of Mickaël Galerne, Valentin Carlac, and Quentin Ollagnier in the preliminary stages of the experiments.

Conflicts of Interest: The authors declare no conflict of interest. The funders had no role in the design of the study; in the collection, analyses, or interpretation of data; in the writing of the manuscript, or in the decision to publish the results. 


\section{References}

1. Guittard, F.; Darmanin, T. Bioinspired Superhydrophobic Surfaces: Advances and Applications with Metallic and Inorganic Materials; CRC Press: New York, NY, USA, 2017.

2. Taleb, S.; Darmanin, T.; Guittard, F. Superoleophobic/superhydrophobic PEDOP conducting copolymers with dual-responsivity by voltage and ion exchange. Mater. Today 2016, 6, 1-8. [CrossRef]

3. Ramos Chagas, G.; Morán Cruz, G.; Giraudon-Colas, G.; Savina, F.; Méallet-Renault, R.; Amigoni, S.; Guittard, F.; Darmanin, T. Ant-bacterial and fluorescent properties of hydrophobic electrodeposited non-fluorinated polypyrenes. Appl. Surf. Sci. 2018, 452, 352-363. [CrossRef]

4. Godeau, G.; Godeau, R.P.; Orange, F.; Szczepanski, C.R.; Guittard, F.; Darmanin, T. Variation of Goliathus orientalis (Moser, 1909) Elytra Nanostructurations and Their Impact on Wettability. Biomimetics 2018, 3, 6. [CrossRef] [PubMed]

5. Mortier, C.; Bourd, R.; Godeau, G.; Guittard, F.; Darmanin, T. Superhydrophobic and superoleophobic poly(3,4-ethylenedioxypyrrole) polymers synthesized using the Staudinger-Vilarrasa reaction. Pure Appl. Chem. 2017, 89, 1751-1760. [CrossRef]

6. Koch, K.; Barthlott, W. Superhydrophobic and superhydrophilic plant surfaces: An inspiration for biomimetic materials. Phil. Trans. R. Soc. A 2009, 367, 1487-1509. [CrossRef] [PubMed]

7. Salapare, H.S., III; Tiquio, M.G.J.P.; Ramos, H.J. Superhydrophilic properties of plasma-treated Posidonia oceanica. Appl. Surf. Sci. 2013, 273, 444-447. [CrossRef]

8. Salapare, H.S., III; Suarez, B.A.T.; Cosiñero, H.S.O.; Bacaoco, M.Y.; Ramos, H.J. Irradiation of poly(tetrafluoroethylene) surfaces by $\mathrm{CF}_{4}$ plasma to achieve robust superhydrophobic and enhanced oleophilic properties for biological applications. Mater. Sci. Eng. C. 2015, 46, 270-275. [CrossRef]

9. Salapare, H.S., III; Blantocas, G.Q.; Rivera, W.L.; Ong, V.A.; Hipolito, R.S.; Ramos, H.J. Anti-bacterial property of hydrogen-ion and oxygen-ion treated polytetrafluoroethylene (PTFE) materials. Plasma Fus. Res. 2011, 6, 2406043.

10. Salapare, H.S., III; Darmanin, T.; Guittard, F. Reactive-ion etching of nylon fabric meshes using oxygen plasma for creating surface nanostructures. Appl. Surf. Sci. 2015, 356, 408-415. [CrossRef]

11. Lee, C.; Graves, D.B.; Lieberman, M.A.; Hess, D.W. Global model of plasma chemistry in a high density oxygen discharge. J. Electrochem. Soc. 1994, 141, 1546-1555. [CrossRef]

12. Salapare, H.S., III; Cosiñero, H.S.O.; Suarez, B.A.T.; Bacaoco, M.Y.; Nuñez, J.A.P.; Guittard, F.; Ramos, H.J. Gas discharge plasma treatment of poly(ethylene glycol-co-1,3/1,4 cyclohexanedimethanol terephthalate) for enhanced paint adhesion. J. Vac. Sci. Technol. A. 2016, 34, 041303. [CrossRef]

13. Adeloju, S.B.; Duan, Y.Y. Corrosion resistance of $\mathrm{Cu}_{2} \mathrm{O}$ and $\mathrm{CuO}$ on copper surfaces in aqueous media. Brit. Corros. J. 1994, 29, 309-314. [CrossRef]

14. Nerle, U.; Rabinal, M.K. Thermal oxidation of copper for favorable formation of cupric oxide $(\mathrm{CuO})$ semiconductor. IOSR J. Appl. Phys. 2013, 5, 01-07. [CrossRef]

15. McDonald, B.T.; Cui, T. Superhydrophilic surface modification of copper surfaces by layer-by-layer self-assembly and liquid phase deposition of $\mathrm{TiO}_{2}$ thin film. J. Colloid Inter. Sci. 2011, 354, 1-6. [CrossRef]

16. Borges, J.N.; Belmonte, T.; Guillot, J.; Duday, D.; Moreno-Couranjou, M.; Choquet, P.; Migeon, H.N. Functionalization of copper surfaces by plasma treatments to improve adhesion of epoxy resins. Plasma Proc. Polym. 2009, 6, S490-S495. [CrossRef]

17. Chang, C.C.; Chen, M.C.; Li, L.J.; Wu, Z.C.; Jang, S.M.; Liang, M.S. Effects of $\mathrm{O}_{2}$ - and $\mathrm{N}_{2}$-Plasma Treatments on Copper Surface. Jpn. J. Appl. Phys. 2004, 43, 7415-7418. [CrossRef]

18. Choudhary, S.; Sarma, J.V.N.; Pande, S.; Ababou-Girard, S.; Turban, P.; Lepine, B.; Gangopadhyay, S. Oxidation mechanism of thin $\mathrm{Cu}$ films: A gateway towards the formation of single oxide phase. AIP Adv. 2018, 8, 055114. [CrossRef]

19. Clayton, C.K.; Sohn, H.Y.; Whitty, K.J. Oxidation kinetics of $\mathrm{Cu}_{2} \mathrm{O}$ in oxygen carriers for chemical looping with oxygen uncoupling. Ind. Eng. Chem. Res. 2014, 53, 2976-2986. [CrossRef]

20. Zhu, Y.; Mimura, K.; Isshiki, M. Oxidation mechanism of copper at 623-1073 K*. Mater. Trans. 2002, 43, 2173-2176. [CrossRef]

21. Jian, G.; Zhou, L.; Piekiel, N.W.; Zachariah, M.R. Low effective activation energies for oxygen release from metal oxides: Evidence for mass-transfer limits at high heating rates. Chem. Phys. Chem. 2014, 15, 1666-1672. [CrossRef] 
22. Praveen, B.; Suresh, S. Experimental study on heat transfer performance of neopentyl glycol/CuO composite solid-solid PCM in TES based heat sink. Eng. Sci. Technol. Inter. J. 2018, 21, 1086-1094. [CrossRef]

23. Yeh, H.H.; Wen, M.C.; Chang, L.; Ploog, K.H.; Chou, M.M.C. Epitaxial growth of $\mathrm{Cu}_{2} \mathrm{O}$ on Cu substrate-A combinatorial substrate approach. J. Crys. Grow. 2019, 512, 124-130. [CrossRef]

24. Ge, P.; Turunen, M.P.K.; Kusevic, M.; Kivilahti, J.K. Effects of surface treatment on the adhesion of copper to a hybrid polymer material. J. Mater. Res. 2003, 18, 2697-2707. [CrossRef]

25. Fritz-Popovski, G.; Sosada-Ludwikowska, F.; Köck, A.; Keckes, J.; Maier, G.A. Study of CuO nanowire growth on different copper surfaces. Sci. Rep. 2019, 9, 807. [CrossRef] [PubMed]

26. Pike, J.; Chan, S.W.; Zhang, F.; Wang, X.; Hanson, J. Formation of stable $\mathrm{Cu}_{2} \mathrm{O}$ from reduction of $\mathrm{CuO}$ nanoparticles. Appl. Catal A: Gen. 2006, 303, 272-277. [CrossRef]

27. Murali, D.S.; Kumar, S.; Choudhary, R.J.; Wadikar, A.D.; Jain, M.K.; Subrahmanyam, A. Synthesis of $\mathrm{Cu}_{2} \mathrm{O}$ from $\mathrm{CuO}$ thin films: Optical and electrical properties. AIP Adv. 2015, 5, 047143. [CrossRef]

28. Suttichart, C.; Boonyawan, D.; Nhuapeng, W.; Thamjaree, W. Effect of a low gas pressure plasma treatment on copper substrate used for carbon nanotubes synthesis. Surf. Coat. Technol. 2016, 306, 279-284. [CrossRef]

29. Yu Fedorov, L.; Karpov, I.V.; Ushakov, A.V.; Lepeshev, A.A. Study of phase composition of $\mathrm{CuO} / \mathrm{Cu}_{2} \mathrm{O}$ nanoparticles produced in the plasma of a low-pressure arc discharge. Inorg. Mater. Appl. Res. 2018, 9, 323-328. [CrossRef]

30. Pal, D.; Neogi, S.; De, S. Surface modification of polyacrylonitrile co-polymer membranes using pulsed direct current nitrogen plasma. Thin Solid Film. 2015, 597, 171-182. [CrossRef]

31. Javid, A.; Kumar, M.; Han, J.G. Study of sterilization-treatment in pure and N- doped carbon thin films synthesized by inductively coupled plasma assisted pulsed-DC magnetron sputtering. Appl. Surf. Sci. 2017, 392, 1062-1067. [CrossRef]

32. Darnon, M.; Petit-Etienne, C.; Pargon, E.; Cunge, G.; Vallier, L.; Bodart, P.; Haas, M.; Banna, S.; Lill, T.; Joubert, O. Synchronous pulsed plasma for silicon etch applications. ECS Trans. 2010, 27, 717-723.

33. Li, Y.; Hess, D.W. Transport considerations in the plasma-assisted oxidation of copper films. J. Electrochem. Soc. 2004, 151, G40-G46. [CrossRef] 